\title{
Individual Retirement Accounts and Other Retirement Savings Plans ${ }^{1}$
}

Josephine Turner ${ }^{2}$

\section{Contents}

Individual Retirement Accounts

\author{
The Basic IRA \\ How IRAs Work \\ Should I Open An IRA \\ Education IRAs \\ Is An IRA Right For You? \\ Selecting The Right IRA Investment \\ Investment \\ Managing Your IRA \\ Moving Your Funds \\ Withdrawing Your Funds \\ What Happens To Your IRA When You \\ Die \\ Other Tax Sheltered Retirement Plans \\ Simplified Employee Pensions \\ 401K Retirement Plans \\ Pre-tax Contribution Limits \\ Total Contribution Limits \\ Catch-up Contribution Limits \\ Keogh Plans
}

\section{Overview}

For many years, Congress has recognized that saving for retirement is a worthwhile social goal and should be encouraged by the government. The federal government has encouraged the growth of private pension and savings plans through the use of various tax incentives. This publication will focus mainly on individual retirement accounts (IRAs), but other plans such as simplified employee pensions (SEPs), 401-K plans, and Keogh plans will be discussed, too.

\section{Individual Retirement Accounts}

An individual retirement account (IRA) is a personal savings plan that lets you set aside money for your retirement. If you qualify, you can use all or part of your contributions to the plan as a tax deduction in the tax year for which you are making the contribution. Also, the earnings (dividends, interest, etc.) that accumulate in an IRA are not taxed until you begin withdrawing the money. This is true regardless of whether all or part of your contributions were taxable when you put them into the IRA.

Before 1987, IRAs were immensely popular because any wage earner, regardless of other pension coverage or amount of earned income, could open and fully deduct an IRA. However, the Tax Reform Act of 1986 reduced the advantages of IRAs for many people. Now IRAs are most beneficial for people with low to moderate incomes and people who do not have pension plans at work.

The Tax Reform Act of 1986 did not change the rules about who can open an IRA, how much can be contributed, or what happens to money already placed in an IRA account. The income earned on allowable IRA contributions still

1. This document is FCS5258, one of a series of the Department of Family, Youth and Community Sciences, University of Florida, UF/IFAS, Gainesville 32611. First published: September 2003. Reviewed by Mary Harrison, professor, Department of Family, Youth and Community Sciences; Brenda Williams, Ed.D., Family and Consumer Sciences agent, Alachua County; and Barbara Mobley, Extension specialist, Family Programs, Alabama Cooperative Extension System, Auburn University, Auburn. Please visit the EDIS Web site at http://edis.ifas.ufl.edu

2. Josephine Turner, Ph.D., CFP, professor, Family and Consumer Economics, Department of Family, Youth and Community Sciences, University of Florida, UF/IFAS, Gainesville 32611.

The Institute of Food and Agricultural Sciences is an equal opportunity/affirmative action employer authorized to provide research, educational information and other services only to individuals and institutions that function without regard to race, color, sex, age, handicap or national origin. For information on obtaining other extension publications, contact your county Cooperative Extension Service office. Florida Cooperative Extension Service/Institute of Food and Agricultural Sciences/University of Florida/Christine Taylor Waddill, Dean. 
accumulates tax-free until withdrawn, and many people still receive an income tax deduction for at least some of the money they contribute to an IRA.

In 1998 a new code section 408A established a new kind of IRA — the Roth IRA. The basic idea of this new IRA is that contributions are not deductible from your income tax, but "qualified distributions" are tax-free. Qualified distributions are distributions made after the owner of the IRA reaches age $591 / 2$ and has held the IRA at least 5 years. In addition to tax-free distributions other benefits are: (1) no minimum required distribution during life; (2) no maximum age for making contributions; and (3) even a favorable rule for tax treatment of "non-qualified" distributions. Details of the tax treatment of IRAs will be discussed later in this publication.

\section{The Basic IRA}

If you are a wage earner under the age of $70 \frac{1}{1} 2$ you can open an IRA account with a governmentdesignated IRA custodian. In 2002 the tax law changed the amount that can be contributed to an IRA. See Table 1 in Appendix A to see how much you can contribute. You may deposit this amount from earned income or your total earned income whichever is less.

As previously stated, all income earned in the IRA account will compound tax-deferred until the money is withdrawn. When the funds are taken out at the allowable age of $591 / 2$ or later, the earnings and any previously untaxed contributions will be taxed as ordinary income. [Remember the Roth IRA is not taxed when "qualified" withdrawals are made. Contributions to a Roth IRA are not tax deductible when made and the withdrawals are made tax free if they are made according to the terms of the Roth IRA agreement.]

IRA contributions are still 100 percent tax deductible for many people. If neither you nor your spouse is covered for any part of the year by a retirement plan at work, you can take a full deduction for your allowable basic IRA contribution no matter how much you earn.

If you are covered by a pension plan, there is a phase-out range that allows you to deduct less and less the more you earn. If you are an unmarried wage earner with a modified adjusted gross income of less than $\$ 34,000$ per year (in 2002), your IRA contribution can be fully deducted even if you are covered by a pension plan at work. Then the phase-out begins, and partial deductions are allowed for single wage-earners with earned income between $\$ 34,000$ and $\$ 40,000$ per year (2002).

The phase-out is figured this way:

1. Enter excess of your modified adjusted gross income (MAGI) over your phase-out threshold. \$

2. Multiply step 1 by $30 \%$ or by $35 \%$ if you were age 50 or older at the end of 2002. $\$$

3. Subtract step 2 from $\$ 3,000$, or $\$ 3,500$ if you were age 50 or older at the end of 2002. \$

4. If step 3 is not a multiple of 10 , round it up to the next highest multiple of $\$ 10$. If the result is under $\$ 200$, increase it to $\$ 200$. This is your deductible limit. $\$$

Example A: Sally Smith is single under age 50 and an active participant in a retirement plan at work. Her MAGI for 2002 was \$35,343. Her MAGI exceeds the $\$ 34,000$ phase-out floor for single persons by $\$ 1,343$ [35,343-34,000]. Sally figured her deductible limit for 2002 of $\$ 2600$ as follows:

Step 1: Excess over phase-out threshold for single persons $(35,343-34,000)=\$ 1343.00$

Step 2: $30 \%$ of step $1=\$ 402.90$

Step 3: $\$ 3000$ minus step $2=\$ 2,597.10$

Step 4: Round step 3 to the next highest multiple of 10 . Deductible limit $=\$ 2,600.00$

If you were one of the dual employed married couples filing jointly in 2002 with an adjusted gross income of less than $\$ 54,000$, you and your spouse each were allowed a \$3,000 IRA contribution. Partial deductions were allowed for married couples filing jointly who earned more than $\$ 54,000$ but less than $\$ 64,000$.

Example B: Eddie and Edith Jones are both under age 50 at the end of 2002 and file a joint return. They reported MAGI of $\$ 57,025$. Both Eddie and Edith were active participants in employer retirement plans at work and therefore were both subject to the $\$ 54,000$ phase-out threshold. The deduction limit for each of them was \$2,100 figured below: 
Step 1: Excess of MAGI over phase-out for married couples, filing jointly $(57,025-54,000)$ $=\underline{\$ 3025}$

Step 2: $30 \%$ of step $1=\$ 907.50$

Step 3: $\$ 3,000$ minus step $2=\$ 2092.50$

Step 4: Round step 3 to the next highest multiple of $\$ 10$. This was the deductible limit for Eddie and Edith. On their joint return they each deducted \$2,100 IRA contributions for a total of $\underline{\$ 4,200 \text {. }}$.

Example C: Assume the same facts as in Example B except that only Edith was a participant in an Employee plan. Eddie and Edith were required to figure out their deduction limits separately using different phase-out thresholds.

For Edith the same \$2,100 (in above example) deduction limit applied. The $\$ 54,000$ phase-out threshold applied. Her MAGI was \$3,025 ( $\$ 57,025$ MAGI on joint return- $\$ 54,000$ threshold). Her deduction limit was $\$ 2,100$. For Eddie the special \$150,000 threshold for nonparticipant spouses applies. Since joint return MAGI is well below the $\$ 150,000$ threshold, he is not affected by the phase-out rules and was able to deduct IRA contributions of up to the $\$ 3,000$ ceiling in 2002.

Many other rules apply to IRAs. These include:

- IRAs are held by individuals only; they cannot be joint accounts.

- Married person may not deduct IRA contributions if he or she files separately, has a pension plan at work, and has an adjusted gross income in excess of $\$ 10,000$.

- If one spouse is unemployed the couple can contribute $\$ 6,000$ (in 2003) to their IRAs as long as no more than $\$ 3,000$ is put in to either person's IRA.

- Individuals may contribute a maximum of \$3,000 into an IRA only if earned income for the year is at least $\$ 3,000$. If earned income is less than $\$ 3,000$ per year, then the most that can be contributed to an IRA is the amount of earned income. (An exception to this is a non-earning spouse as described above.)

- Earned income includes wages, salaries, fees, commissions, bonuses, tips, and self-employment income. Passive income, such as interest, dividends, and profits from the sale of your house, does not count as earned income. Once you retire, your company pension and Social Security checks also are treated as passive income.

\section{How IRAs Work}

There is no required minimum contribution in order to begin an IRA. However, a financial institution may set its own minimum contribution for opening an IRA account. Once you establish an IRA, you may contribute to the account as infrequently as you wish; in fact, you may contribute only once and never contribute again if that is your preference.

However, you may not "double up" your contributions in later years, because the maximum contribution allowed in any one year is $\$ 3,000$. If you contribute more than the $\$ 3,000$ maximum you will not be allowed to deduct the amount over $\$ 3,000$. You will also have to pay a 6 percent penalty tax on all excess contributions if you do not withdraw the excess by the due date of your tax return. See catch up provision for exception in Appendix A.

Example: Paul forgot the maximum allowed in an IRA and contributed \$4,000 in 2002 to an IRA account. He will pay 6 percent, or $\$ 60$, on the extra $\$ 1,000$ each year that it is left in the account.

One exception to this rule against doubling up occurs because IRA contributions must be made by the time you file your income tax return, usually April 15. The account must be established and funded by that time. This means that it is possible to put $\$ 6,000$ into the IRA in the same calendar year. For example, any time before April 15,2004 , you may contribute $\$ 3,000$ for 2003 . If on April 1, 2004 you contribute $\$ 3,000$ for year 2003, you may also contribute on April 1, 2004 an additional \$3,000 for 2004. Of course, you will maximize the compounding of interest if you contribute as early in the tax year as possible.

You may set up as many IRA accounts as you like and contribute to all of them each year, as long as you do not exceed the $\$ 3,000$ total annual limit. Moreover, your IRA account can hold many types of investments. You may invest in almost anything including stocks, bonds, mutual funds, mortgage-backed securities, and annuities. You may not invest your IRA funds in "collectibles" such as jewelry, art, or antiques. 
You may not withdraw your IRA money until you are $591 \frac{1}{2}$ years old. Otherwise, you may be penalized 10 percent of all money you withdraw before that time. There are exceptions, such as for certain disabilities or death. In addition, the money withdrawn prematurely will be taxed as ordinary income. However, you must begin to withdraw your funds by age $701 / 2$ for basic or regular IRAs. Withdrawals will be discussed in more detail later.

\section{Should I Open An IRA?}

Although IRAs are popular, they are not for everyone. One disadvantage to IRAs that applies especially to lower-level wage earners is the lack of liquidity. If you withdraw the funds that you place in an IRA before you reach $591 / 2$ you will have to pay a heavy penalty unless you withdraw because of disability or meet the requirements for other exceptions.

If you are on a tight budget and you have not built up comfortable savings, you may be forced because of an emergency to dip into your IRA account before age $591 \frac{1}{2}$. On the other hand, even if you do withdraw IRA funds early and have to pay a penalty, the penalty may be less than the earnings you have accumulated by putting the money away, it may be worth it.

Another drawback to consider, if your earnings are relatively low, is that you will gain less than higher-income people from the tax benefits of an IRA since you are in a lower tax bracket to begin with. This is particularly true if you think your tax bracket will be higher when you retire than it is now. An IRA would backfire under these circumstances since you postpone paying taxes on the IRA until you retire.

Middle-income earners face similar concerns and also need a source of savings that is readily available to draw upon without penalty. If you are middle-income and will soon face big lump-sum bills such as college expenses for children or a balloon payment on a house, consider setting aside money for these events before you open an IRA.

\section{Education IRAs}

The Education IRA or Coverdell Education Savings Account allows parents, grandparents, and others to contribute to a college fund for a named beneficiary under age 18. In 2002 annual contributions per child from all sources could be as much as $\$ 2,000$.
Contributions to these accounts receive no tax benefit. That is contributions are not tax deductible. They however can be withdrawn for approved educational expenses tax-free. Any earnings not used for qualified educational expenses are included in the gross income of the beneficiary in the year benefits are received. Please note that a $10 \%$ penalty tax may be charged against any withdrawals not used for education.

The good news for parents with more than one child is that a tax-free and penalty free rollover of account balance can be made to a Coverdell ESA to benefit a younger child. Like that Roth IRA, eligibility for contributions to a Coverdell ESA phases-out at an AGI of $\$ 95,000$ to $\$ 110,000$ for single tax files and $\$ 190,000$ to $\$ 220,000$ for married joint filers in 2002.

\section{Is An IRA Right For You?}

A middle-income self-employed person may not find that an IRA best suits his or her needs if reinvesting money in the business would produce more benefit. Periodic reinvestment might be needed to keep the business prosperous and may provide more long-term security than an IRA. Also, self-employed people often have more volatile incomes than salaried employees, which may make it more difficult to invest in an IRA. In low-income years, investment may not be affordable; in high-income years, an IRA investment may not provide enough of a tax shelter to offset the higher income.

Wealthier people may find that an IRA does not provide enough of a benefit to shelter their income or they don't qualify for an IRA. Higher deductions are allowed for a Keogh plan, SEP, or 401-K plan. These plans are discussed later. Still, every tax break helps, and an IRA can be maintained even if a Keogh or SEP is used. Another consideration is that high-income people may have a large income in their retirement years, and delaying their tax payments may be of little use since their tax bracket will be high when they retire.

If you are over age 60, many experts believe that you would probably not benefit much from a traditional IRA because you will not be allowed to contribute to it beyond age 70`1/2. (A Roth IRA has no such rules.) This simply may not allow you enough time to build up very substantial savings, and another savings program may benefit you more. 
Finally, if taxes go up over time, the advantage of putting money in an IRA today goes down. For example, if you are in the 28 percent tax bracket now, but your bracket increases to 35 percent because Congress raises taxes by the time you withdraw your IRA, your financial strategy would not be successful. However, your income will probably be less when you retire than it is now; moreover, Congress is currently considering ways to make IRA investments more attractive in an attempt to encourage Americans to save. Finally, making no preparations for old age may prove the riskiest strategy of all.

On the positive side, IRAs can lower the tax burden now for those people who take a deduction for contributions. Even if you cannot take a deduction for your contribution, you can postpone any taxes on the earnings of your contributions because the earnings are taxed when you withdraw your funds.

Another advantage of IRAs is their flexibility. You can contribute as little as you like each year, or choose not to contribute at all. An IRA is easy to open, requiring little paperwork. You can also select the type of investment strategy you prefer for you IRA - that is, whether to invest conservatively or aggressively. In short, for many people, the IRA is still an excellent investment strategy.

\section{Selecting The Right IRA Investment}

You should consider carefully the types of investments that are right for your IRA. Generally, more risky investments offer higher returns. More conservative investments usually pay a lower return, but you have less chance of losing your money altogether. In deciding the type of IRA investment for you, think about the following six factors:

1. How old are you? Generally the financial experts say that the younger you are, the more risk you can afford to take because you have more time to recover from a bad investment. On the other hand, the younger you are, the more time inflation has to erode your investment; therefore, you must aim for more earnings to offset inflation.

2. What is your level of income and assets? More affluent people can afford to be more aggressive in their investment portfolios simply because they have other assets to fall back on if they lose money on their IRA investments.

3. Do you have an existing pension plan? If you are sure you have a good retirement nest egg already, you can afford to be a bit bolder in your investment strategy.

4. How much risk are you emotionally willing to take? Even if you are young or have a high income or a pension, you may dislike the uncertainty of risk. If you are quite un-comfortable about possible loss, invest in slower-growing, safer investments. If you can tolerate moderate risk, consider more volatile investment options.

5. How much do you know about investing and how much time are you willing to spend managing your money? In general, if your investment expertise is low, keep your investments simple. Often, the more aggressive the investments are, the more complicated they will be. Also, if you haven't the interest or the time to monitor your investment, you should probably consider safe, simple IRA investments such as a bank money market account or CD.

6. How large is your existing IRA? The larger it is, the more you should diversify it.

(See Appendix B for a worksheet designed to help savers compare IRAs.)

\section{Investment}

Now that you have decided to invest, let's consider where you should put your IRA.

Most financial institutions, including banks and other savings institutions, mutual funds, brokerage firms, and life insurance companies, are government-designated IRA custodians.

Banks and Savings Institutions. Banks and savings institutions are usually considered the safest places to invest your IRA funds. Of course, if an investment is considered very safe, it usually means that growth is slower. Because of safety and convenience, most of the IRA market is invested at banks and savings and loans. Many people also like the simplicity of the programs of savings institutions. 
Banks and savings institutions usually offer, among other things, certificates of deposit and some form of bank money market account. A certificate of deposit is a savings arrangement in which you contract with a banking institution to leave your investment there for a specified period of time such as 6 months or 1 year. The banking institution pays you a higher interest on the money than you would earn in a regular savings account.

The general rule is that the longer you commit to leave your money, the higher your interest will be. Shop around the different institutions to find the best interest rate, but be sure you understand how the rate is figured. Since calculating interest rates can get complicated, experts advise you to compare the effective annual yield offered at each institution. Effective annual yield reflects the amount you actually make, once the complications of compounding or other factors such as bonuses offered by the institution are considered.

Certificates of deposit at banks are insured by the federal government up to $\$ 100,000$. Some stock brokerage firms also offer certificates of deposit, although they are not insured.

Frequently a bank will offer a brokerage service so that you can purchase other types of investment instruments. Of course, a commission or fee is usually charged for this service.

Mutual Funds. A mutual fund is a pool of money collected from many investors that is jointly invested by professional money managers. In effect, a mutual fund is a collection of stocks, bonds, and other securities held in one package by a company. Mutual fund plans can be purchased directly from mutual fund companies or though banks or stock brokers.

By buying a share of the mutual fund package, the investor gains the advantages of spreading his or her financial risk over many types of investments and of relying on the expertise of the fund's manager. However, investors should be knowledgeable of the fund's sales charge, operating expenses, and performance record.

Some experts say that mutual funds offer a moderate risk with more growth potential than certificates of deposit. These experts suggest mutual funds for people with moderate to high incomes who feel comfortable with a slight risk and who seek some diversification in their IRA investments.
Brokerage Firms. Stock brokerage firms and some banks offer the widest variety of investment options for your IRA by providing for a selfdirected account. This investing strategy offers more hands-on management by the investor.

With a self-directed IRA account, an investor chooses a brokerage firm or discount brokerage, and then selects an assortment of investments that best suits his or her needs. With a full-service brokerage at a brokerage firm, the investor receives investment advice from a broker in exchange for a commission. A "discount broker" charges less than a full-service broker but does not provide investment advice or other such services. Discount brokerage may be offered at brokerage firms or at some banks.

The major advantage to the self-directed account investment option is diversification. In a single account, an investor can hold the different types of securities that match the investor's requirements for growth and safety. The major drawback is that most require initial and annual fees, but these fees are tax-deductible. Another drawback is that the investor may not wish to spend the time managing the account.

Experts recommend the self-directed accounts for holders of larger IRAs and other retirement savings plans worth $\$ 10,000$ or more, because of the greater ability to diversity. Younger highincome investors, who can afford to take some risk, can benefit from self-directed accounts if they already have another retirement plan, because it allows for growth and aggressiveness. More conservative investors may benefit from selfdirected accounts because of the flexibility they allow.

Insurance Companies. Insurance companies offer IRA investments in the form of annuities. Annuities guarantee regular payment to you, the investor, for the rest of your life. As with regular IRAs, annuities allow up to a $\$ 3,000$ contribution per year in 2002, 2003 and 2004. See Appendix A.

Two types of annuities are:

- Fixed-rate annuities, which pay interest based on how well the insurance company does on some of its investments.

- Variable annuities, which operate in a fashion similar to a mutual fund. 
These types of plans offer considerable security since the investor is guaranteed income for his or her life. You should be aware of all fees and withdrawal penalties attached to these plans, however, as the plans often are quite expensive. Consider also how often interest is compounded, since compounding interest is of critical importance to the growth of the investment. Finally, you may be able to obtain the advantages of fixed income for the rest of your life by transferring your IRA funds to an insurance company when you retire and have them provide the annuity at that point.

If you purchase a "joint-and-survivor" annuity, your beneficiary will also receive a lifetime annuity if he or she survives you. Once both you and your beneficiary have died, any funds that are left will pass to the insurance company.

\section{Managing Your IRA}

Once your IRA funds have begun to grow, you may wish to consider diversifying your funds so that, as the saying goes, all of your eggs are not in one basket. Or you may have other reasons to consider moving your money from the original custodian, such as to respond to changes in the securities markets or changes in your personal finances. At any rate, IRA funds are not complicated.

\section{Moving Your Funds}

There are two ways to switch your IRA format. One is a do-it-yourself procedure known as a rollover. The other procedure, the transfer, is done for you by your IRA custodian.

Rollover. With the rollover, you simply tell your present IRA custodian to close your account (or to withdraw a portion of your funds if you are not closing the account) and give you the check. You then take the check and deposit it in your new IRA account. These withdrawals are tax-free as long as you reinvest the funds by the sixtieth day after the day you receive the money from your IRA.

If you do not reinvest within the 60-day time period, the withdrawals will be treated as a taxable distribution from your IRA plan. As discussed above, this means you must include the withdrawal in your ordinary income to be taxed, and also pay a 10 percent tax on premature distributions if your age is under 59 1/2. Rollover distributions from each IRA may be made only once a year. This one-year period begins on the date you receive the IRA distribution, not on the date you reinvest it. This rule applies separately to each IRA you own.

Be sure to ask about fees your IRA custodian might charge before you shift your funds.

Transfers. The second way to shift your funds is to request the IRA custodian to transfer your funds. Usually you must put the request in writing. This method will take longer than a rollover. Before requesting the transfer, be sure to check with the new custodian to be certain that all of your assets will be accepted. This is particularly important if you own stocks or annuities.

One option for switching your funds without worrying about the rollover and transfer rules is through mutual fund telephone switching. Through this service, you can switch your money from one mutual fund to another, but your money stays in the same company. Because your money stays in the same account, you need not worry about meeting the rules of rollovers or transfers. Many mutual fund companies offer this switching service.

Many people contribute to their own IRAs while also contributing to other retirement plans, such as Keoghs, 401-Ks, SEPs, and private pensions. One word of caution, though: The rules governing transfers from other retirement plans into IRAs are quite complex. You should seek professional advice from a broker or financial planner before you make such a transfer because you may be dealing with large sums of money. The penalties for incorrect withdrawals are severe.

\section{Withdrawing Your Funds}

The general principle is that the longer you leave your money in your IRA account, the more income it will generate. However, you must begin withdrawals from your traditional IRA when you reach the age of $701 / 2$. [You don't ever have to make any withdrawals from your Roth IRA.]

You have two options in receiving the balance of your traditional IRA. You may receive the entire amount by April 1 of the year following the year in which you reach $701 / 2$, or you may begin receiving periodic payments of the balance by April 1 of that year. 
You are also required to withdraw all of your IRA money within a specified time limit. The amount of time you are allowed to keep money in your IRA after you reach age $701 / 2$ depends upon your life expectancy or the joint life and last survivor expectancy of yourself and your designated beneficiary. Life expectancy is figured according to actuarial tables used by the IRS.

See IRS Publication 590 for more details on withdrawals from your IRA, consult your tax advisor or financial planner. It is important that you withdraw your IRA funds according to the rules because you could be taxed 50 percent on the excess amount that remains in your IRA account. [The IRS can waive the penalty if it determines that you have a good reason for allowing an excess accumulation to remain in your IRA account.] Withdrawing from Roth IRA is not mandatory. You can leave your Roth IRA to your heirs.

\section{What Happens To Your IRA When You Die}

If you die before you have taken out all of your IRA funds, your IRA goes to the beneficiary or beneficiaries you have specified. The beneficiaries then have several options, depending on their wishes and the rules of your IRA custodian. Since some of these options offer special tax advantages, your beneficiary should consult an accountant or tax advisor concerning the account.

\section{Other Tax-Sheltered Retirement Plans}

IRAs are fairly easy to begin and maintain, and they can accumulate generous earnings to a careful saver. There are other tax-sheltered retirement plans that may also appeal to you which allow even greater retirement savings, such as SEP-IRA, 401-K, and Keogh plans.

\section{Simplified Employee Pensions}

A simplified employee pension (SEP) is one of the three major alternatives to an IRA. It is a special retirement plan for the self-employed person and his or her employees. The plan allows the employer to contribute each year up to 25 percent of the employee's compensation or $\$ 40,000$, whichever is less, to a retirement plan for the employee. The advantage of a SEP is that it allows a larger contribution per year than an IRA does.
SEPs were established in 1978 so that small companies employing 25 or fewer people could set up retirement programs for their employees. An employer who has set up a SEP program may place money into your account each year. This means the contribution will not be included in your income. The money placed in your account becomes your money and is subject to most of the same rules as an IRA contribution. This is why SEPs are sometimes called SEP-IRAs. The employer is not required to place a certain amount in your account, as long as the maximum limits are not exceeded, nor is the employer required to make any contribution at all.

A SEP must be set up on behalf of all eligible employees and must meet the requirements of the Internal Revenue Code. If you are self-employed, you may also set up a SEP-IRA and treat yourself as an employee for SEP-IRA purposes.

A SEP may include an arrangement whereby you can choose to have your employer make contributions to the SEP-IRA out of your salary. This choice is called an elective deferral. In order for an elective deferral to be available, certain requirements must be met:

- At least 50 percent of the employees of your employer must choose to have amounts contributed to the SEP-IRA.

- Your employer must not have more than 25 employees at any time during the preceding year.

- The amount deferred each year by each employee who is considered "highly compensated" must be no more than 125 percent of the average percentage of deferral of all other employees. This rather complex formula ensures that highly paid employees do not receive overly large tax deductions while lower-paid employees receive tiny deductions.

This elective deferral arrangement is not available for a SEP that is maintained by exempt organizations, state or local government, or their agencies.

Your employer's contribution to your SEPIRA is not included in your Form W-2, Wage and Tax Statement, and you do not include these contributions in your gross income. In addition to the contributions your employer makes, you can make contributions to your SEP-IRA and deduct 
them the same way you deduct contributions to your regular IRA.

Like IRA accounts, SEPs are subject to penalties if your employer or you contribute too much. Generally speaking, these penalties include a 6 percent excise tax on excess amounts that remain in your SEP-IRA. In addition, you must pay an additional 10 percent tax on the amounts you withdraw prematurely, and those prematurely withdrawn funds must be treated as taxable income for that year.

Your bank, broker, or other IRA custodian can help you set up a SEP-IRA. Basically, you and your employer must complete IRS Form 5305SEP, and then make the contribution.

In summary, a major advantage of a SEP-IRA over an IRA is that you can contribute much more to the SEP account than you can to an IRA. Moreover, you can still maintain your own separate IRA. The SEP-IRA is an easy-to-start flexible benefit for small companies to provide their employees, although some employers may not want to take part because it requires some administration. Self-employed individuals also may find this method of accumulating taxdeferred earnings attractive.

\section{1-K Retirement Plans}

Another retirement plan that receives special tax treatment goes by several different names. But whether it is called a "salary deferral plan," a "cash or deferred plan," a "salary reduction plan," or simply a "401-K plan" (this name comes from the section in the Internal Revenue Code that governs this type of plan), this retirement plan has definite advantages. Eligible employees of nonprofit organizations such as churches, colleges, hospitals, etc. may contribute to a 403(b) plan that has the same limits as a 401(K). Employees of county, state and local government and non-profit organizations may contribute to 457 plans. The media usually uses $401(\mathrm{~K})$ plans to cover all of the above.

Individual retirement accounts and SEP-IRAs are similar to $401-\mathrm{K}$ plans in that you can reduce your taxable income while saving for your retirement. However, instead of you opening the account yourself, the money in a 401-K plan goes into your employer's profit-sharing plan. Unlike SEP-IRAs, any firm, not just small companies, can offer a 401-K.
The way it works is that your employer, at your request, withholds a specific amount from your paycheck and invests it in a special account that will be administered by the company. You will usually have an option on how you want the funds invested. The funds placed into a 401-K are considered deferred compensation and are not reported to the IRS as income. For example, if you made $\$ 30,000$ in 2002 and deposited 5 percent, or $\$ 1,500$, into your $401-\mathrm{K}$, you would have reported only $\$ 28,500$ for federal income tax purposes that year.

Your contributions must usually remain in the 401-K account until you leave the job, reach age $591 / 2$, die, or become disabled, although you may be able to withdraw the funds if you have a "hardship." As with IRAs and SEPs, if you withdraw the funds in a manner not allowed by the IRS, you will have to pay a 10 percent penalty. You will also have to accept the funds as taxable income for that year.

One of the major advantages to a $401(\mathrm{~K})$ is that there are generous limits to contributions. These limits of contributions can be categorized in three ways: pre-tax contributions, total contributions and catch-up contributions. All limits are imposed by the IRS.

\section{Pre-tax Contribution Limits}

The Economic Growth and Tax Relief Reconciliation Act of 2001 establishes the limits on your pre-tax contributions to the following in each year: $\$ 11,000$ in 2002, $\$ 12,000$ in 2003, $\$ 13,000$ in 2004, $\$ 14,000$ in 2005 and $\$ 15,000$ in 2006. After 2006, the limit is indexed in $\$ 500$ increments for inflation. (Thus $\$ 15,500$ is set as the limit for 2007). However, your company may set the maximum at a lower amount. In 2002 the limit for individuals over 50 years of age is $\$ 12,000$ and in 2003 the limits increase to $\$ 14,000$.

\section{Total Contribution Limits}

The IRS has also set annual limits on the total amount that may be contributed to your $401(\mathrm{~K})$ account. This limit for 2002 is the maximum of $\$ 40,000$ or $100 \%$ of compensation, whichever is less and is the combined total of your contribution plus any employer matching or profit-sharing contributions plus any after-tax contributions you as the employee may make. The $\$ 40,000$ limit is set to increase by $\$ 1,000$ increments based on cost 
of living adjustments (COLAs). Again, your company may set the maximum at a lower amount than the $\$ 40,000$ IRS maximum.

\section{Catch-up Contribution Limits}

Starting in 2002 persons age 50 and older can make additional catch up contributions as follows:

\begin{tabular}{ll}
\hline 2002 & $\$ 1,000$ \\
\hline 2003 & $\$ 2,000$ \\
\hline 2004 & $\$ 3,000$ \\
\hline 2005 & $\$ 4,000$ \\
\hline 2006 & $\$ 5,000$ \\
\hline
\end{tabular}

As with SEP-IRAs, 401-K plans have rules to be sure that the plans do not discriminate against lower-paid employees. The amount that higherpaid employees may contribute may have to be reduced under these rules if lower-paid employees do not participate as fully.

$401 \mathrm{~K}$ plans have several advantages. They allow you to contribute more funds than the $\$ 3,000$ allowed for the Traditional IRA. You may also have the benefit of matching contributions made by your employer.

Allowing someone else to save for your retirement is a benefit of considerable significance. In addition, you can defer the tax on any earnings from assets in the plan, and you may subtract your contribution from your income without paying taxes on it. Taxes are paid when you withdraw income at retirement. This can go a long way in reducing tax-liability.

The major disadvantage of a $401-\mathrm{K}$ is that you have less flexibility about choosing investments and varying the amount of contributions than you have with an IRA. Moreover, 401-K plans are difficult to find, so if such a plan is offered at your place of employment, seriously consider taking advantage of it.

\section{Keogh Plans}

One important tax shelter that allows enormous tax-deductible savings for retirement is a Keogh plan. A Keogh plan is complex and subject to technical rules, so you should consult a tax advisor when setting up the plan.

A Keogh allows self-employed people (sole proprietors or partners) to make large taxdeductible contributions for themselves and their eligible employees. The plan must meet certain legal requirements to qualify for tax benefits.
Employers/owners may deduct contributions to a Keogh. Employees usually may not deduct contributions to the plan. However, the earnings on employee contributions are not taxed until the employee's share in the plan is distributed.

If you are self-employed, you may make contributions to a Keogh generally only if you have net earnings from that self-employment. For example, if you have a full-time job but also have a part-time business, you can contribute only the earnings from the part-time business to the Keogh. Generally, there are two kinds of Keogh plans, defined contribution plans and defined benefit plans. Different rules apply to each.

A defined contribution plan is the most common plan. With this type of plan, benefits are based primarily on the amount contributed to each account. As a self-employed person, you decide each year how much you want to contribute, up to certain limits. Under a defined contribution plan, the limit of total annual plan contributions is $\$ 40,000$ or a stated percent of your net selfemployed earned income, whichever is less.

There are two kinds of defined contribution plans, profit-sharing plans and money-purchase plans. Profit-sharing plans are generally (though not always) based on the employer's profits. The employer is allowed to deduct contributions of up to a set percent of the participants' compensation. You do not have to contribute the same percentage every year or make any contributions at all.

Money-purchasing plans, on the other hand, require that you make the same percentage contribution each year. This percentage is decided upon when the plan is set up, but it can be changed if you wish.

The other type of Keogh, the defined benefit plan, allows you to save extremely large amounts of tax-deferred retirement savings. Contributions to a defined benefit plan are based on a calculation of what contributions are necessary to meet the retirement goals you determine. To determine the amount of this annual contribution, you must get actuarial calculations. These must be done each year based on earned income, planned expenses, and other factors. This type of Keogh is especially helpful for older people who want to take fast, large steps toward a comfortable retirement.

The major advantage of Keoghs is that they allow large retirement savings and large tax deductions. 
The major disadvantage of Keoghs is that there is a lot of paperwork in setting them up and the penalties are more serious than for other types of investments if you do not abide by IRS rules. In fact, the entire plan could be disqualified from tax sheltering if the IRS rules are violated. Still, if you seek professional assistance, the Keogh plan may be the best tax break around for the self-employed person.

\section{Caution}

Pension plans are complex, as are the tax laws governing them. Furthermore, laws change often. Those that applied when you began a retirement account may have changed.

This publication has given an overview of some basic points about retirement plans, but it is not a "how-to" manual. Your retirement income is too important to take chances with. Seek professional assistance in setting up and managing a retirement plan.

\section{References}

Internal Revenue Service. Publication 590.

Washington, D.C.: Government Printing Office.

Garman, E. Thomas and Forgve, Raymond E.: Personal Finance, 7th Ed. New York, Houghton Mifflin Co. 2003

Lasser's, J.K. Your Income Tax 2003. New York: John Wiley \& Sons, Inc. 2002.

O'Neill, Barbara and others. Investing for Your Future. New York: Natural Resource, Agriculture and Engineering Service Cooperative Extension. 2002.

Stokes, Barrie Balzli, J.D. Personal consultation.

Tax-Savings Plans For The Self-Employed. Chicago: Commerce Clearing House, Inc., 1989.

Turner, Josephine. Individual Retirement Accounts and Other Retirement Savings

Plans.

Circular HE-628. Auburn, Alabama. The Alabama Cooperative Extension System. 1992. 


\section{Appendix A}

IRA contribution limits during the years 2002-2008 are provided in Table 1. After 2008, maximum IRA contributions are inflation-adjusted in \$500 increments.

\begin{tabular}{cccc}
\hline $\begin{array}{l}\text { Table } 1 \\
\text { Contribution amounts for traditional (tax-deferred), nondeductible and Roth IRAs }\end{array}$ \\
YEAR & $\begin{array}{c}\text { CONTRIBUTION } \\
\text { CIMIT }\end{array}$ & $\begin{array}{c}\text { CATCH-UP } \\
\text { CONTRIBUTION } \\
\text { (AGE 50 OR OLDER) }\end{array}$ & $\begin{array}{c}\text { MAXIMUM } \\
\text { CONTRIBUTION } \\
\text { (AGE 50 OR OLDER) }\end{array}$ \\
2002 & $\$ 3,000$ & $\$ 500$ & $\$ 3,500$ \\
2003 & 3,000 & 500 & 3,500 \\
2004 & 3,000 & 500 & 3,500 \\
2005 & 4,000 & 500 & 4,500 \\
2006 & 4,000 & 1,000 & 5,000 \\
2007 & 4,000 & 1,000 & 5,000 \\
2008 & 5,000 & 1,000 & 6,000 \\
\hline
\end{tabular}

\section{Appendix B}

\section{Shopping for an IRA}

The worksheet below is designed to help savers compare IRAs. Talking to IRA specialists at various financial institutions can also be helpful. IRA owners will want to assess their willingness to take risks, age, retirement income goals, and the relative safety of their investment options. Generally speaking, the closer to retirement, the more conservative the investment choice, especially if you'll be depending on IRA dollars as a major income source.

The custodian of trustee generally must give the IRA owner a disclosure statement at least seven days before the IRA is set up. The custodian or trustee can provide the statement on the date the IRA is set up, however, if the investor is given seven days from the set-up date to revoke the IRA.

Carefully read the disclosure statement, which will explain the income-tax consequences of opening and maintaining an IRA. Most custodians provide a financial projection table to project growth at the end of each of the first five contract years and at ages 60,65, and 70. The disclosure statement must also specify start-up and annual management costs, when and how the IRA can be revoked, and the name, address and telephone number of the person designated to receive the notice of cancellation. 
Worksheet: Shopping for an Individual Retirement Account (IRA)

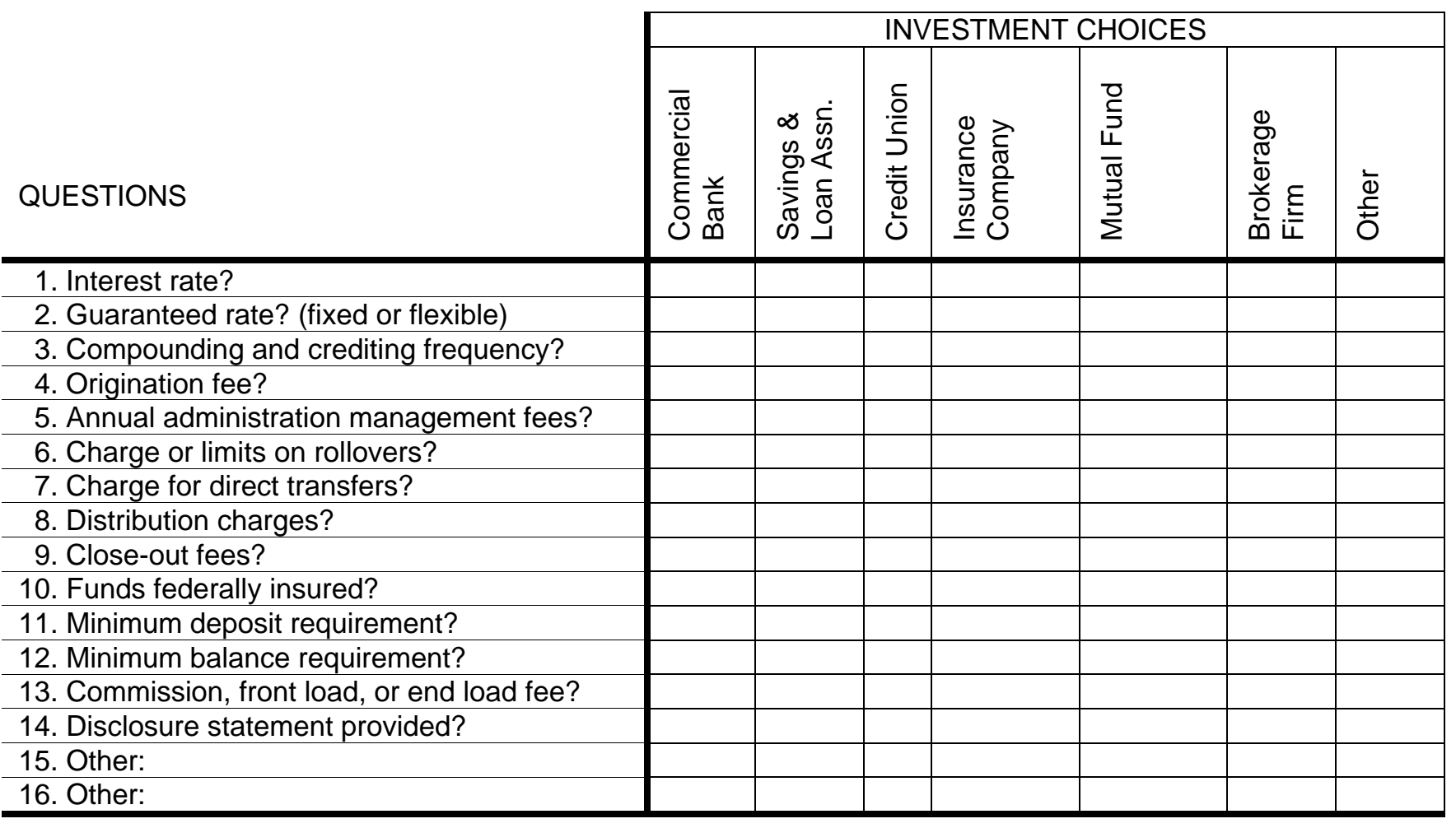

\section{PROJECTED GROWTH}

Amount you'll have at the end of -

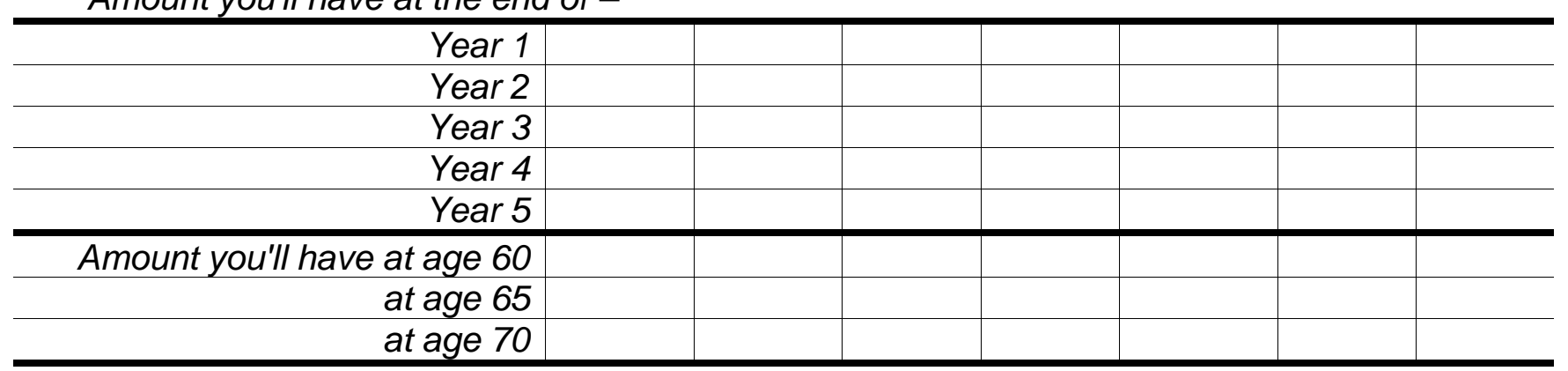

\begin{tabular}{|l|c|c|}
\cline { 2 - 3 } \multicolumn{1}{l|}{ Traditional IRA vs. Roth IRA } & Traditional IRA & Roth IRA \\
\hline Annual contribution amounts in 2003 & $\$ 3000$ & $\$ 3000$ \\
\hline Initial amount Tax deferred & Yes, if you qualify & No \\
\hline Interest Tax deferred & Yes & $\begin{array}{c}\text { Interest is not taxable under } \\
\text { current law }\end{array}$ \\
\hline Age to withdraw without penalty & $591 / 2$ & $59 \frac{1}{1 / 2}$ and 5 years in Roth IRA \\
\hline Required withdrawal must begin by & $701 / 2$ & No required withdrawal \\
\hline
\end{tabular}

